\title{
Missed Painless Testicular Torsion in Adult Patient
}

\author{
Jayed Alenzi M, Sultan J Alanazi*, Abdulaziz WF and Thamer Manwer Albalasi \\ College of Medicine, Aljouf University, Saudi Arabia
}

Submission: January 25, 2017; Published: February 09, 2017

*Corresponding author: Alenzi MJ, College of Medicine, Al jouf University, Saudi Arabia, Email: mja@ju.edu.sa

\section{Introduction}

The most common cause of a urological emergency related to the genitourinary tract is a highly painful one called testicular torsion. Men have two testicles that rest inside the scrotum. The spermatic cord carries blood to the testicles. When a man experiences torsion of testes, this cord twists. As a result, blood flow is affected and declined to testicular tissue then, the tissues in the testicle started to die. It is affecting 3.8 per 100,000 males younger than 18 years annually [1]. It is about $10 \%$ to $15 \%$ of acute scrotum in children [2], and results in an orchiectomy rate of $42 \%$ in boys undergoing surgery for testicular torsion [3]. The torsion usually occurs in the absence of any precipitating event [3]; only 4 to 8 percent of cases are a result of trauma [4] Rapid growth during puberty may also cause the condition.

Proper diagnosis and treatment are very important for testicular salvage, and torsion must be excluded in all patients who present with acute scrotum. Pain and swelling of the scrotum are the main symptoms of testicular torsion. The onset of pain may be quite sudden, and the pain can be severe. Swelling may be limited to just one side, or it can occur in the entire scrotum. You may notice that one testicle is higher than the other, associated sometimes with nausea, and vomiting [4]. Physical examination may reveal a high-riding testicle with an absent cremasteric reflex. If history and physical examination suggest torsion, immediate surgical exploration is indicated and should not be delayed to perform radiological investigations. There is typically a four- to eight-hour window before permanent ischemic damage occurs [5]. Delay in treatment may be associated with decreased fertility, or may end by orchiectomy.

\section{Case Report}

A 28 years old male was visiting the accident and emergency department with the history of left side scrotal swelling since 10 days. It was painless swelling in the same side. The swelling increased in size. No history of medical illness associated with it. No history of trauma. No history of fever. On clinical examination, Vital signs were stable. Abdomen was soft, lax and no organomegally. External genitalia looked normal except right side was huge swelling, non-tenderness and no hotness. Leftside looked normal in size and shape. Laboratory results like CBC, Biochemistry and bleeding time were within the normal range. Doppler ultrasound was done showing absence of blood flows in the testis and epididymis. In Operation theatre, left side scrotal exploration was performed and the testis was very black and necrotized" (Figure 1 \& 2)". The left orchiectomy" (Figure 3)" was done and right testis was fixed. Hemostasis was secured and dressing was done. Antibiotics and analgesia were given.
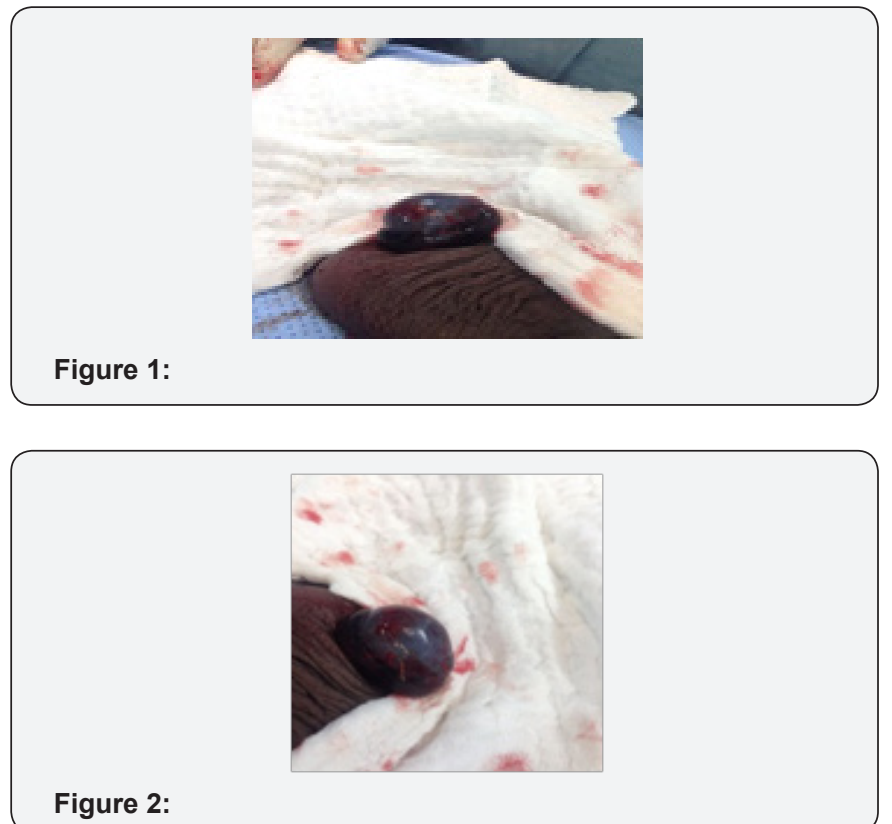

Figure 2:

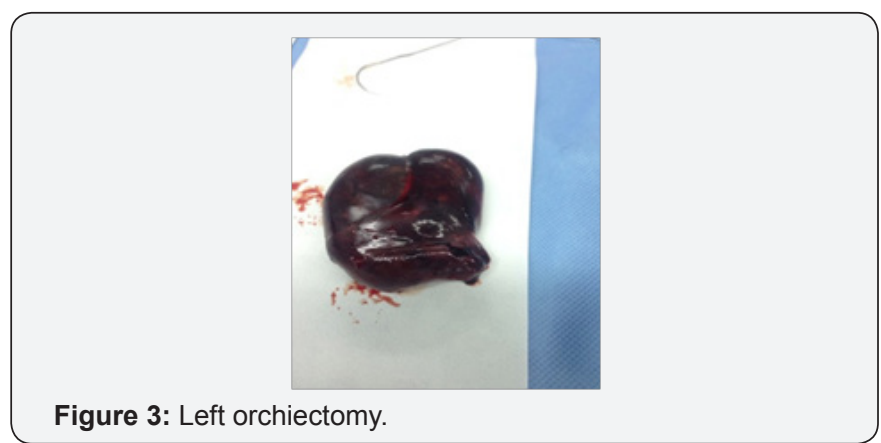




\section{Discussion}

Currently, In adolescents or young adults the more common torsion in intravaginal. The most common underlying abnormality is the so-called bell clapper deformity which allows the testis (and attached epididymis) extensive mobility, and thus places it at risk of twisting around the spermatic cord [6]. Initially, torsion is sufficient only to obstruct venous outflow (incomplete torsion, less than 360 degrees), resulting in the gradual increase in intratesticular pressure and resistance. Over time and with an additional twisting of the cord (greater than 360 degrees), the arterial inflow is also obstructed, and the testis becomes entirely ischemic [7] in mature adult when he complaint, he should go directly to hospital or primary health care. In our case, the patient denied any pain or complaints just he felt a swelling. It's possible for some men to experience what's known as intermittent torsion.

This causes a man to have a testicle twist and untwist. Because the condition is likely to recur, it's important to seek treatment, even if the pain subsides. According to the Mayo Clinic, 95 percent of men treated for testicular torsion within six hours of the onset of pain don't ultimately require testicle removal. However, an estimated 90 percent of men do require surgical removal of the testicle if treatment is delivered 48 hours or more after the pain starts. Orchiectomy can affect production of hormone. Also it can cause fertility in future by decreasing the sperm count. It may create anti-sperm antibodies from dead testis, and this also can decrease sperm motility [8-10].

\section{Conclusion}

From that, the people health education is very important to distribute the knowledge between the parents and the adults.
You can examine you genitalia every time to preserve you're an important organs. For that, the people health education is very important to distribute the knowledge among the population. Also, the use of social media to distribute the information play a role in health education and lower the sensitivity through the males from complaining of symptoms of external genitalia.

\section{References}

1. Thomas WE, Cooper MJ, Crane GA, Lee G, Williamson RC (1984) Testicular exocrine malfunction after torsion. Lancet 2(8416): 13571360.

2. Romeo C, Impellizzeri P, Arrigo T, Antonuccio P, Valenzise M, et al. (2010) Late hormonal function after testicular torsion. J Pediatr Surg 45(2): 411-413.

3. Bartsch G, Frank S, Marberger H, Mikuz G (1980) Testicular torsion: late results with special regard to fertility and endocrine function. J Urol 124(3): 375-378.

4. Kapoor S (2008) Testicular torsion: a race against time. Int J ClinPract 62(5): 821-827.

5. Bhatt S, Dogra VS (2008) Role of US in testicular and scrotal trauma. Radiographics 28(6): 1617-1629.

6. Wolf K (1995) Color duplex sonography, principles and clinical applications. Thieme.

7. Eaton SH, Cendron MA, Estrada CR, Bauer SB, Borer JG, et. al. (2005) Intermittent testicular torsion: diagnostic features and management outcomes. J Urol 174(4 Pt 2): 1532-1535.

8. Margolies L (2016) Breaking the Cycle of Shame and Self-Destructive Behavior. Psych Central.

9. Noske HD, Kraus SW, Altinkilic BM, Weidner W (1998) Historical milestones regarding torsion of the scrotal organs. JUrol159(1): 13-16.

10. Seng YJ, Moissinac K (2000) Trauma induced testicular torsion: a reminder for the unwary. J Accid Emerg Med 17(5): 381-382.
Your next submission with Juniper Publishers will reach you the below assets

- Quality Editorial service

- Swift Peer Review

- Reprints availability

- E-prints Service

- Manuscript Podcast for convenient understanding

- Global attainment for your research

- Manuscript accessibility in different formats

( Pdf, E-pub, Full Text, Audio)

- Unceasing customer service

Track the below URL for one-step submission https://juniperpublishers.com/online-submission.php 